\title{
The Effect of Institutional Factors on the Profitability Risk in the Insurance Companies Listed in the Saudi Stock Market
}

\author{
Abdulaziz Mohammed AlSahlawi ${ }^{1}$ \\ ${ }^{1}$ Department of Finance, College of Business Administration, King Faisal University, Al-Hasa, Saudi Arabia \\ Correspondence: Abdulaziz Mohammed AlSahlawi, Department of Finance, College of Business Administration, \\ King Faisal University, Al-Hasa, Saudi Arabia. E-mail: amalsahlawi@kfu.edu.sa
}

Received: May 1, 2018

Accepted: May 21, 2018

Online Published: June 5, 2018

doi:10.5539/ibr.v11n7p12

URL: https://doi.org/10.5539/ibr.v11n7p12

\begin{abstract}
This paper conducted an investigation into the effect of institutional factors namely, leverage, capital market assets, and firm size on the risk of profitability among Saudi insurance companies listed in the Saudi Stock market (Tadawul). The paper also determined if the institutional theory has a significant impact on the profitability risk of Saudi insurance firms. On the basis of the findings from the multiple regression analysis that was conducted on the data obtained, the study's institutional factors namely, leverage, capital market assets, and firm size had a significant relationship with the return on assets of the Saudi insurance companies, which in turn, increased their profitability. In other words, the findings supported the contribution of leverage, capital market assets and firm size to the profitability of Saudi insurance companies and provided considerable directions as to developing a strategy of profitability among the companies.
\end{abstract}

Keywords: institutional factors, profitability risk, insurance companies, Saudi Arabia

\section{Introduction}

The influence of institutional factor like firm size, leverage and capital on the profitability of Saudi insurance companies listed in the Saudi Stock Market began gaining attention owing to the dynamic changes occurring the Saudi landscape throughout the years that highlights the country's economy (Bloomberg, 2017). Saudi Arabia's dependence on oil and gas gave it the impetus to shift towards developing its non-oil economic sectors (World Bank, 2017). As such, the country is currently focusing on the financial economic aspect and Saudi financial managers are laying increasing stress on the financial capabilities of the nation. In this regard, Doh and Teegen (2012) indicated that finances form the blood of business entities.

According to Hofstrand (2015), profit is deemed to be the major goal of all companies. This is realized by companies through the offering of goods/services that consumers need at a price that is reasonable to produce and maintain profitability (Khan \& Jain, 2014). Generally speaking, the firm seeks to generate attractive goods/services to obtain profits and create a strong customer base supported by an unrivalled competitive advantage in the market and as such, it is the management's responsibility to exert effort and spend time in enhancing profitability (Joy, 2015). A business that fails to achieve the above functions will experience and incur operational losses (Mitchell et al., 2015).

Moreover, businesses have to earn enough profit in order to maintain their survival and developing in the long-run. Therefore, profit can be considered as the directory as to how the economy can be developed, the national revenue can be increased and the way of lives enhanced. According to Khan and Jain (2014), profitability cannot be over exaggerated and in this regard, management has to maximize profit but this does not mean that they should overlook the societal welfare. In other words, profitability of a company serves as a reward for owners and also for the other societal members (Hofstrand, 2015).

In the above background, efficiency in companies leads to profitability, and in turn, profitability is considered to be a measurement of the former and a guide for management to realize greater efficiency in operations (Prasanna, 2010). Nevertheless, the profitability level cannot be considered as the be-all and end-all evidence of efficiency, despite the fact that profitability is an important measurement for it (Mitchell et al., 2015). Stated clearly, operational efficiency change is one of the determinants of profitability, with several other factors affecting it (Hofstrand, 2015). Such factor include institutional factor namely, leverage, firm size and capital assets. Added 
to this, profitability is gauged by using rates of return in relation to the size of the company, with the results of size linked to the volume of capital market assets (Mitchell et al., 2015). Leverage is another factor that shareholders and creditors have to keep their eye on - more specifically, this refers to the amount of debt that the company has and its ability to pay interest and the principal. The greater the amount of debt, the higher will be the possibility that the company may not be able to repay it. When the company's debt is compared to those of others, the concept used is often leverage ratio. The leverage ratio is also referred to as solvency ratio and it is primarily utilized to gauge the level of the assets of the company that are financed by the incurred debt (Hofstrand, 2015).

According to financial analysts, there is a slow rate in rising profitability in the insurance stock market in Saudi Arabia, as the economy is diversified coupled with the emphasis to shift from oil to non-oil sectors (World Bank, 2017). In 2016, Saudi profit expectation decreased by $0.4 \%$, while the stocks of the developing nations increased by $18 \%$ forward earnings in the same period (Gulf Base, 2017). In the Saudi insurance sector, a boom in insurance investors urged the Saudi shares to increase in price compared to other developing countries and this minimized the interest of investors even in the face of implemented measures by the Saudi Capital Market in an effort to maximize revenues and resuscitate the growth of the economy (Bloomberg, 2017). Such measures/reforms pertained to adapting value-added sales tax and fees for foreign residents, including initial public shares offering from the government-owned Saudi Arabian Oil Co. (World Bank, 2017).

In this paper, focus is placed on the factors of the institutional theory including capital market assets, firm size and leverage. Only a few studies have delved into the implications and effects of such factors on profitability, particularly in insurance field (Hofstrand, 2015). This study therefore examines the effect of leverage, capital market assets and the size of the firms on the profitability of insurance companies listed on the Saudi Stock Exchange (Tadawul). The study also aims to confirm if the institutional theory significantly impacts the profitability risk of the Saudi insurance firms.

The study findings indicated that the institutional factors focused on in this study, which are leverage, capital market assets, size of the firms, all have a significant relationship with the insurance companies' return on assets (ROA) and thus increasing their profitability. The multiple regression analysis was conducted on the obtained data and the findings showed that leverage, capital market assets and the size of the insurance firms contributed to the ROA while providing directions in the development of their strategies of profitability. The results thus support the proposed theoretical framework in the study.

The rest of the paper is organized in the following sections. Section 2 contains the background of Saudi Arabian insurance industry setting and Section 3 contains the review of relevant literature. This is followed by Section 4 that provides a discussion of the research methods used in the study and Section 5 presents the study findings. Lastly, Section 6 contains the paper conclusion.

\section{Institutional Setting of Saudi Arabia}

\subsection{The Saudi Stock Exchange}

The Saudi Stock Exchange (Tadawul) has full control over the Saudi Arabian stock exchange operations, and the trading and security listing of companies. Tadawul also provides post-trade services like depository services involving services registry of the following products; listed and unlisted securities, Sukuk and bounds, whereas the securities pledging that entails securities transfer, Sukuk and bonds and ETF ownership are covered by External Trust Fund (ETF). The companies services also include over-the-counter trading for privately-placed Sukuk and bonds, and market data services that are related to different types of trading activities. Tadawul company is located in Riyadh Saudi Arabia and initial operations began in 2007 (Bloomberg, 2017).

In relation to the above, the Saudi Arabia Capital Market Authority (CMA) is the government's financial regulatory authority that oversees the country's capital markets. CMA is a government entity that is fully independent in terms of financial, legal and administrative aspects and is directly related to the Prime Minister's office. The CMA's main responsibilities include establishing and policing financial rules and regulations and developing the capital markets through regulations of stock exchange (Zawya, 2017). Accordingly, the CMA is granted with the legal and administrative power to inform the Council of Ministers and it protects and oversees the capital markets entire activities. The CMA also investigates inconsistencies, prosecutes hidden trading, erroneous stock holders, money laundering and other fraud types. It can grant warnings, suspend trading and impose fines as need be, where serious offenders relating to disputes in securities are forwarded to the committee for judgment and issuance of sanctions to punish them (Al-Bassama, 2015). 


\subsection{Insurance Industry in Saudi Arabia}

The insurance market of Saudi Arabia has notably been the fastest developing markets in the present times. The Saudi insurance industry was categorized in 2013 into 9 sub-segments, including health insurance that grossed $51 \%$ in the insurance market. The growth of such insurance market in Saudi Arabia is primarily related to the mandatory health insurance program implementation. Meanwhile, the motor insurance market constitutes 36\% of the market's gross written premium, followed by property and casualty insurance constituting $20 \%$, and the Pensions \& Savings constituting 3.3\%. Moreover, a significant average annual growth of $17.5 \%$ was reported in the Saudi Insurance Industry, making the market one of the fastest growing ones in the world. In fact, the market's gross achieved SAR25.2 billion (2016), an increase from SAR14.6 billion (2009) (Zawya, 2017).

By 2015, the Saudi licensed insurance and reinsurance companies numbered 35, 28 of which are qualified by the Cooperative Health Insurance Council to provide services of medical insurance. The major 3 insurance companies in Saudi Arabia are Tawuniya, Bupa Arabia and Medgulf, in control of 54.1\% of the overall insurance market -of the remaining 9 insurance companies are in control of $27.1 \%$ while the remaining 23 are in control of 18.8\% (Albilad Capital Report). With regards to the vehicle insurance market, the market is led by Malath Insurance, Tawuniya and Med Gulf in this order (The Gulf Base, 2017). This type of insurance constitutes the highest position and an outstanding outlook when compared to the rest of the sub-segments in general insurance.

The motor insurance gross premiums accounted for $48.2 \%$ of shares in general insurance, with a $3 \%$ registered growth rate driven largely by the mandatory motor insurance component. The growth has also been attributed to the country's limited public transportation services, cheap subsidized fuel and wealth (Bloomberg, 2017).

Furthermore, Saudi Arabia has transformed into a potential market for Takaful insurance with promising future developments. In the current times, the country has the top position in the global takaful insurance market and the establishment of the mandatory medical insurance requirements is expected to boost the domestic sector (Central Intelligence Agency, 2017).

\subsection{Vision 2030}

Recent developments pertaining to the Vision 2030 of the Kingdom noted the Saudi Deputy Crown Prince, Mohammed bin Salman's announcement of the launching of Saudi Arabia's National Transformation Plan (NTP), wherein the Vision formed the core in the transformation of the Kingdom's economy. Vision 2030 establishes an extensive plan concerning the promotion of efficient running of government services and the diversification of the economy through the considerable role of the private sector, where jobs are created and the non-oil economy is developed (Waddock \& Boyle, 2015). The plan was outlined for budget and society updates, while power is maintained, and higher female integration into the workforce (Saudi Gazette, 2017).

More specifically, a plan has been established by Vision 2030 focused on the development and economic aims of the country for the next decade and a half. The vision is expected to provide a robust, thriving and steady economy for the country. The country is hoping to facilitate enhanced business prospective with the private sector utilizing the three pillars namely, functioning as the core of the Arab and Islamic worlds, being the leader of investment capabilities and occupying a strategic geographic position (Saudi Gazette, 2017). The goals enumerated in the vision included the enhancement of the business environment to improve and maintain the flourishing economy, enhance healthier service opportunities for locals and maintaining long-term financial welfare (Saudi Gazette, 2017).

\section{Literature Review and Hypotheses Development}

\subsection{Institutional Theory}

The institutional theory is a theory considered to have a robust social structure and features that lays emphasis on several structures namely, policies, schemes, norms, rules and routines. Guidelines have made the institutional theory a top standard for social behavior and an institutional perspective is referred to as the valid procedures that control human behavior, business and economy. It is focused on the importance of the environment that surrounds entrepreneurship in the face of dynamic changing businesses.

It is evidenced that institutional factor may not have an instantaneous impact on profitability but overlooking its impact on the profitability of shareholders would be erroneous. The institutional factor is pertinent owing to its governing of incongruity that stems from the lack of effective market infrastructures. An effective institution would lead to increased potential for higher profitability and this includes adapting to a new policy of exchange rate (Kaldaru \& Parts, 2017). 
This study's adoption of the institutional theory is considered suitable owing to the present situation in the Saudi Stock Market's listed insurance firms. The CMAs regulations have placed the whole insurance industry under close scrutiny and supervision of institutions. This theory was deemed suitable as the CMA highlights the institutional factors that impact the securities of shareholders and the profitability of insurance listed firms. The proceeding sections provide discussions on the institutional factors.

\subsection{Capital Market Assets}

Market capitalization refers to the total outstanding shares value that is related to the publicly traded firm. It is an important market indicator of the stocks value and the firms value. Majority of prior studies, including Oluleye and Olajire (2001) revealed the significant role of profitability in providing clarity to the market factors and the ever-changing market price and market ratios. In a related study, Dias (2013) examined the role of market capitalization in estimating value-at-risk and they reported that methods of value-at-risk are conducted in different ways for portfolios having different market capitalization.

\subsection{Size of the Firm}

The firm size can affect the organization's actions in achieving its aims. According to Shaheen and Malik (2012), the firm size encapsulates the number of people and the capital amount, which includes the gathering of the ability of manufacturing, the opportunities that the firm possesses and the quantity and the types of services offered to customers. The firm size is an important institutional factor in the current-day businesses owing to the economies of scale (Logsdon \& Van Buren, 2008), where large-sized firms are able to offer products at lower costs compared to small-sized ones.

Present-day organizations attempt at maximize their size in order to gain competitive advantage over rivals via cost differentiation strategy and offering more products to the market. A sustainable association was noted by Shaheen and Malike (2012) between the size of the company and its profitability, indicating the close relationship between the two factors. Their findings provided empirical evidence of the relationship between firm size (formal and informal) and their profitability. In particular, formal firms are higher in productivity and larger compared to their informal counterparts.

Moreover, with the growth of small firms, their productivity is decreased by evasion and transformation costs (Ebben, 2015) and the existence of evasion costs goes hand in hand with the state of continuum between the two firm sizes (Blackman, 2014). The company size expansion from small to big expects enhancement of business productivity (Ebben, 2015). In fact, the small firm sector is considered as a free micro-entrepreneurial sub-division rather than a segment of the labor market. Small informal firms themselves think that they are voluntary firms opting for an optimal level of contribution to formal firms (Garcia \& Kawamura, 2014). In this background, formalization appears to be an unnecessary resource for firms in the small firms sector and some policy implications may be linked to the firm size characteristics. With the increase in size of small firms, management tasks increase, rendering the decrease of productivity and eventually profitability.

\subsection{Leveraging}

A leverage is described as an investment strategy that involves the use of borrowing to contribute to the expected return on assets (ROA) (Knopik \& Moerer, 2014) and this is why it is generally known as debt utilized for assets financing. In the field of financial literature, there are several theories, concepts and analysis that pertain to profit profiles of firms (Rowly, 2007). The primary reasons are profitability significant in the assessment of business efficiency and determination of the ambiguities that involve the leverage-profitability relationship (Tily, 2014). Therefore, the gap between the two factors has yet to be thoroughly examined necessitating the analysis of profit profile of the firms and examination of the effect of financial leverage on profitability, which this study is attempting to do.

Several empirical studies have been dedicated to examining the leverage-profitability relationship (Preston \& Shapienza, 2014) but with mixed results. Some authors reported a positive leverage-profitability relationship, others reported a negative one, while some others reported the absence of relationship (Prasanna, 2010).

Decisions formed around capital structure primarily concentrates on the appropriation between debt and equity as to the firm's financing pattern. The financial manager of the firm should focus on the optimization of capital structure as it is one of the significant objectives of financial management. According to corporate finance researchers, a relationship exists between the value of the firm and its capital structure in such a way that the terms cannot be separated from each other. Capital structure is a significant firm performance aspect that has been the topic of discussion among financial researchers for a long period. It is thus expected that capital structure's affect on business value is of great significance. 
On the basis of the above discussion, this study proposes the following hypotheses for testing;

H1: There is a relationship between capital market asset and profitability of Saudi listed insurance firms.

H2: There is a relationship between company size and profitability of Saudi listed insurance firms.

H3: There is a relationship between leverage and profitability of Saudi listed insurance firms.

\section{Research Methods}

\subsection{Data Collection}

Following prior studies, this paper hand collected data from annual reports of 30 insurance companies available in Tadawul website, and information from the official websites of the insurance companies themselves. Some additional data was also gathered from the Zawya.com, GulfBase.com and Bloomberg.com.

\subsection{Measurement of Variables}

Profitability, as the dependent variable in this study, is measured by Return on Assets (ROA). ROA primarily measures the level to which the company's assets are able to produce profits. The ratio gauges the ability of the company to produce net income under specific assets level. ROA can be calculated by using the following formula;

\section{ROA=Net Income/Total Assets}

The greater the profitability ratio, the greater will be the company's generated profits in a specific period. With regards to the independent variables, they are measured in this study in the following way;

The market assets are measured by multiplying the outstanding company shares by the current market price of a single share. The company size is gauged through log of total assets, and leverage by dividing the total debt by total assets.

\subsection{Model Specifications}

To meet the study objectives and determine the impact of institutional factors of capital market assets, firm size and leverage, on listed insurance companies profitability, the Ordinary Least Squares Regression (ORS) was employed in this study;

$R O A$

$$
=\beta_{0}+\beta_{1} C A P I T A L+\beta_{2} S I Z E+\beta_{3} L E V E R A G E+\varepsilon_{i}
$$

Where:

$\begin{array}{lll}\text { ROA } & = & \text { Net income to total assets } \\ \text { CAPITAL }= & \text { Multiplying a company's shares outstanding by the current market price of one } \\ & \text { share } \\ \text { SIZE } & =\text { Log of total assets } \\ \text { LEVERAGE }= & \text { Total debt to total assets }\end{array}$

\section{Result and Discussion}

The summary of the institutional factors of the insurance companies are tabulated in Table 1 and they were applied for the analysis of the institutional theory effects. From the table, it is presented that the mean of leverage is 1.93 , mean of capital is 4.8 , mean of the company size is 2.17 , and mean of ROA is 1.33 . Moreover, the median of leverage is 0.96 , capital assets median 498.407 and the firm size median is 2 .

Table 1. Institutional Factors Statistics

\begin{tabular}{lccccc}
\hline & $\mathrm{N}$ & Range & Mean & Std. Deviation & Variance \\
\hline Leverage & 30 & 11 & 1.93 & 2.432 & 5.913 \\
Capital & 30 & 8.00 & 4.8000 & 2.32527 & 5.407 \\
Size & 30 & 2 & 2.17 & .874 & .764 \\
ROA & 30 & 4 & 1.33 & .803 & .645 \\
Valid N (listwise) & 30 & & & &
\end{tabular}

From the statistics, it is evident that the range between the highest and lowest value of leverage is 11, between that of capital is 8.0, and between firm size is 2 . With regards to the ROA, the difference between the highest and lowest value is 4 , indicating that the variables range is interlinked.

Table 2 presents the results of the Multiple Regression Analysis and the influence of the institutional factors 
namely, capital assets, leverage and firm size, on the return on assets (ROA).

Table 2. Regression Analysis Coefficients of ROA, Leverage, Capital, and Size of the Insurance Firms

\begin{tabular}{|c|c|c|c|c|c|}
\hline & \multicolumn{2}{|c|}{ Unstandardized Coefficients } & \multirow{2}{*}{$\frac{\text { Standardized Coefficients }}{\text { Beta }}$} & \multirow[t]{2}{*}{$\mathrm{t}$} & \multirow{2}{*}{ Sig. } \\
\hline & $\mathrm{B}$ & Std. Error & & & \\
\hline (Constant) & 2.486 & .496 & & 5.011 & .000 \\
\hline Leverage & .037 & .058 & .113 & .647 & .523 \\
\hline Capital & -.104 & .059 & -.300 & -1.767 & .089 \\
\hline Size & -.338 & .160 & -.368 & -2.114 & .044 \\
\hline
\end{tabular}

a. Dependent Variable: ROA

Based on the results obtained, $\left(p<.0005\right.$, with $\left.R^{2}=.251\right)$. The sum of the independent variables was found to be statistically significant to predicting profitability at $(p<.05)$, and hence, the study hypotheses are accepted. According to the institutional theory, leverage, capital and firm size have significant effects on ROA/profitability, in this case, among Saudi listed insurance companies. The institutional factors of leverage, company size and capital function as guidelines for the customers/shareholders' social behavior, while the company vision and mission represent their compliance to these institutional factors.

Both customer and shareholder circles of the insurance companies gain advantage from the schemes, norms, rules, routines, and policies (Zawaideh, 2016). Meanwhile, the companies' size facilitates extensive reach to provide variety of services to customers.

\section{Conclusion}

In the present study, the effect of institutional factors namely, capital market assets, firm size and leverage on profitability risk, among Saudi listed insurance companies in the Saudi Stock Market, were examined and based on the findings, all the examined institutional factors were found to have a significant effect on the insurance companies' profitability.

This study has several implications to various circles. Firstly, it may assist insurance companies in identifying their profitability through the application of institutional factors in a consistent manner, and in guiding their established policies and norms. In other words, the institutional factors examined can act as a guide for insurance companies listed in the Saudi stock exchange. Added to this, effective orientation and training may contribute to fine-tuning the mental framework of the insurance firms when it comes to the consideration of the institutional theory. Insurance companies in the Saudi Stock Exchange can promote awareness among shareholders of the necessity to enhance their understanding of financial risks and how to build protection against financial risks via sufficient savings, insurance and financial entities.

Moreover, the shareholders of insurance firms may leverage the institutional factors practices based on institutional theory. The shareholders will in turn value their investments and place their trust on insurance companies concerning the effective management of the capital investment. Empirical findings from this study indicated that the interest of shareholders should be focused on leverage, capital, firm size and return on assets (ROA) as these institutional factors are important in selecting the investments with the top profitability.

Although this study did not cover the entire institutional factors owing to lack of numerical data for the regression computation of the predictor variables, it dealt with the three top institutional factors, which are leverage, capital and firm size and the results are sufficient to provide indication of the significant influence of the factors on the listed Saudi insurance companies' profitability. This study recommends that future research examine the effect of other institutional factors not covered by the present one, like liquidity management and ownership structure, on the companies profitability risk.

\section{References}

Albassam, B. A. (2015). Does Saudi Arabia's economy benefit from foreign investments? Benchmarking: An International Journal, 22(7), 1214-1228.

Blackman, A. (2014). How to measure your business's profitability, Envato tuts + Today. Retrieved from http://business.tutsplus.com/tutorials/how-to-measure-your-businesss-profitability--cms-20674

Bloomberg (2017). IMF Sees 2017 Saudi Growth 'Close to Zero' on Oil Prices, Cuts. Retrieved from https://www.bloomberg.com/news/articles/2017-07-21/imf-sees-2017-saudi-growth-close-to-zero-on-oil-pri ces-cuts

Bloomberg (2017). Tawaniya. Retrieved from https://www.bloomberg.com/quote/ TAW UN I YA:AB

Bloomberg (2017). The Saudi Stock Exchange. Retrieved from https://www.bloomberg. com/ research/stocks/private/snapshot.asp?privcapId=27134345 
Central Intelligence Agency (2017). The World Fact Book: Saudi Arabia. Retrieved from https://www.cia.gov/library/publications/the-world-factbook/geos/sa.html

Dias, A. (2013). Market capitalization and Value-at-Risk. Journal of Banking \& Finance, 37(12), 5248-5260. https://doi.org/10.1016/j.jbankfin.2013.04.015

Doh, J. P., \& Teegen, H. (2012). Nongovernmental organizations as institutional actors in international business: theory and implications. International Business Review, 11, 665-684. https://doi.org/10.1016/S0969-5931(02)00044-6

Ebben, J. J. (2015). Cash Conversion Cycle Management in Small Firms: Relationships with Liquidity, Invested Capital, and Firm Performance, Journal of Small Business and Entrepreneurship, 24(3), 381-396. https://doi.org/10.1080/08276331.2011.10593545

Garcia, J. \& Kawamura, E. (2014). Central bank liquidity management and unconventional monetary policies. Economia. Peru: Brookings Institution Press. Retrieved from https://www.jstor.org/stable/24368350

Gulf Base (2017). Saudi Stock Exchange. Retrieved from https://www.gulfbase.com/marketwatch-saudi-stock-exchange-1

Hofstrand, D. (2015). Understanding profitability. Iowa State University Extension and Outreach. Retrieved from

http://www.zawya.com/mena/en/company/The_Mediterraneanand_Gulf_Cooperative_Insurance_and_Reins urance_Company-1004782/

Joy, O. M. (2015). Introduction to Financial Management, New Delhi, Prentice-Hall, 423-440.

Kaldaru, H., \& Parts, E. (2017). Social and institutional factors of economic development: Evidence from Europe. Baltic Journal of Economics, 8(1), 29-51. https://doi.org/10.1080/1406099X.2008.10840444

Khan, M. Y., \& Jain, P. K. (2014). Financial Management, New Delhi, India: Tata McGraw Hill Publishing Company Limited, 264-280.

Knopik, M. S., \& Moerer, T. (2014). Women leaders and entrepreneurs: exploring the interpersonal behaviors of developing, maintaining, and leveraging social capital, Academy of Entrepreneurship Journal, 20(1), $37-45$.

Logsdon, J. M., \& Van Buren, H. J. (2008). Justice and large corporations: What do activist shareholders want? Business \& Society, 47(4), 523-548. https://doi.org/10.1177/0007650308316524

Mitchell, R. K., Agle, B. R., \& WoodSource, D. J. (2015). Toward a Theory of Stakeholder identification and salience: Defining the principle of who and what really counts, The Academy of Management Review, 22(4), 853-886. https://doi.org/10.5465/amr.1997.9711022105

Oluleye, A. E., \& Olajire, K.A. (2001). Productivity and profitability trends in an environment of reform. Integrated Manufacturing Systems, 12(3), 205-210. https://doi.org/10.1108/09576060110391165

Prasanna, C. (2010). Financial Management, Theory and Practice, New Delhi, India: Tata McGraw Hill Publishing Company Limited, 260-270.

Preston, L. E., \& Shapienza H. J. (2014). Stakeholder Management and Corporate Performance, Journal of Behavioural Economics, 19, 361-375. https://doi.org/10.1016/0090-5720(90)90023-Z

Rowly, T. J. (2007). Moving beyond dyadic ties: A network of theory of stakeholders' influences, Academy of Management Review, 22(4), 887-910. https://doi.org/10.5465/amr.1997.9711022107

Saudi, G. (2017). Full Text of Saudi Arabia Vision 2030. Business. Saudi Gazette, Riyadh, Saudi Arabia.

Shaheen, S., Malik, Q. A. (2012). The impact of capital intensity, size of firm and profitability on debt financing in textile industry in Pakistan. Interdisciplinary Journal of Contemporary Research in Business, 3(10), 1061-1066.

Tily, G. (2014). Keynes's theory of liquidity preference and his debt management and monetary policies. Cambridge Journal of Economics 30, 657-670. https://doi.org/10.1093/cje/bei104

Waddock, S.A., \& Boyle, M. E. (2015). The dynamic of change in corporate community relations, California Management Review, 37(4), 125-140. https://doi.org/10.2307/41165814

World Bank (2017). Saudi Arabia, GCC: Economic outlook in April 2017.

Zawaideh, M. (2016). The Normative Approach. Explanation of Intrinsic Stakeholder Commitment of Berman, 
Wicks, Kotha, Jones and Freeman. Balanced Scorecard, Retrieved from https://www.xing.com/communities/posts/the-normative-approach-explanation-of-intrinsic-stakeholder-com mitment-of-berman-wicks-kotha-jones-and-1004177948

Zawya (2017). The Mediterranean and Gulf Cooperative Insurance. Retrieved from http://www.zawya.com/mena/en/company/The_Mediterranean_and_Gulf_Cooperative_Insurance_and_Rei nsurance_Company-1004782/

\section{Copyrights}

Copyright for this article is retained by the author(s), with first publication rights granted to the journal.

This is an open-access article distributed under the terms and conditions of the Creative Commons Attribution license (http://creativecommons.org/licenses/by/4.0/). 